\title{
License to Mine: A Comparison of the Scope of the Environmental Assessment in Sweden, Finland and Russia
}

\author{
Maria Pettersson', Anniina Oksanen'2, Tatiana Mingaleva3 ${ }^{3}$, Victor Petrov³, \\ Vladimir Masloboev ${ }^{3}$ \\ ${ }^{1}$ Department of Social Sciences, Luleå University of Technology, Luleå, Sweden \\ ${ }^{2}$ Faculty of Law, University of Lapland, Rovaniemi, Finland \\ ${ }^{3}$ Institute of Industrial Ecology Problems in the North, Kola Science Centre, Russian Academy of Science, \\ Apatity, Russia \\ Email: Maria.Pettersson@ltu.se
}

Received 26 February 2015; accepted 8 April 2015; published 13 April 2015

Copyright (c) 2015 by authors and Scientific Research Publishing Inc.

This work is licensed under the Creative Commons Attribution International License (CC BY).

http://creativecommons.org/licenses/by/4.0/

(c) (i) 0 pen Access

\section{Abstract}

The regulatory framework for mining operations is complex; the licensing process in particular typically involves several laws and a number of permits. This paper assumes that the regulatory framework is strongly influenced by the institutional framework of which it is part, and that it suffers from an institutional path dependence that may decrease the efficiency of the system as well as act barrier to the implementation of necessary environmental requirements. The paper provides: 1) a legal analysis of the regulatory framework governing mining operations in Sweden, Finland and Russia; and 2) a comparative analysis of the scope of the environmental assessment within the licensing process in the examined countries. The result of the analysis of the regulatory frameworks shows great similarity between the Swedish and the Finnish systems, both in terms of the overall structure and the implementation of substantive environmental rules. The Russian system differs in this respect, with more declarative rules and seemingly less substantive assessments. The results also indicate that the regulatory frameworks in all three countries show signs of institutional path dependence, but in very different degrees. Though Russia has indeed implemented major changes in the formal structure, very little has changed in practice. The Swedish regulatory framework for mining shows a deficient systematics and conflicting objectives, despite the implementation of a comprehensive environmental legislation. The recently reformed Finnish system seems to have a more holistic approach.

\section{Keywords}

Legal Framework, Licensing Process, Environmental Law, EIA, Mining Industry, Institutional 


\section{Framework, Path Dependence}

\section{Introduction}

In Sweden, Finland and Russia, the licensing of new mines and the expansion of production in existing mines involve several different laws, ordinances and regulations as well as a number of permits, including environmental impact assessment (EIA) and strategic environmental assessment (SEA). The chain of permits that are required before mining can commence or expand is here referred to as "licensing process". The licensing of new mines also encompasses extensive consultation and participation procedures, including appeal possibilities. International conventions and EU-law add to the intricacy of the situation.

Mining law research is relatively scarce in Sweden. Existing studies include the work of Digman [1] and Delin [2] [3]. Although these studies hold considerable relevance, they were made before the advent of the 1998 Environmental Code and therefore do not cover much of the legal conditions applicable to the mining industry today. The legal system governing exploration and exploitation of minerals has also been studied more recently by Bäckström [4] and Liedholm Johnson [5], but from the perspective of civil law and property science, not including the environmental aspects of the licensing or the scope of the integrated assessment. While the process of planning and permitting of industrial facilities such as wind power plants and the function of law in relation to the use of natural resources have previously been examined (e.g. [6]-[8]), these studies do not target mining.

In Sweden, the current environmental permitting process is based on case-to-case assessments of new industrial plants or production expansion at existing plants. The assessment and the resulting regulations and conditions rely heavily on the criteria outlined in the Environmental Code. During the recent decade, this process has been intensely criticized: it is claimed to be unpredictable, subjective, time-consuming, and in lack of coordination across different government authorities while simultaneously suffering from incomplete regulatory knowledge about mining operations [9]. Similar concerns have been raised with respect to the permitting process for new energy production plants in Sweden (e.g. [10]). The interrelationship between the different legal rules that regulate mining in Sweden thus needs to be clarified, and the advantages and disadvantages of the integrated assessment adequately assessed. The case law developed under the Swedish Environment Code is partly contradictory. The Land and Environmental Court of Appeals has in some cases revoked the permit issued by the lower court on the grounds that the assessment was too limited (i.e. the city tunnel in Malmö) and, in other cases parts of the activity were permitted (i.e. the Botnia railway). When it comes to mining, the question arose as late as in 2011 when the Land and Environmental Court of Appeal decided to revoke the lower court decision to grant a license for new mining in the municipality of Svappavaara on the grounds that the application did not encompass existing mining related activities in the area [11]. Also, the social impacts of mining are easily overlooked in the Swedish system since Social Impact Assessments (SIA) are not required by law. While some companies conduct SIAs on their own initiative, others do not; this creates an unequal situation for the communities affected by the mining operation.

Unlike Sweden, Finnish mining law has been studied in some detail even in recent times (e.g. [12] [13]), which can be explained by the 2011 revision of the Finnish Mining Act. The Finnish licensing process is similar to the Swedish one: several permits are required and granted on a case-to-case assessment. The 2011 revision aimed at enhancing the possibilities account for environmental and social issues as well as to better enforce the conditions for exploration and exploitation [14] (p. 1). For discussion prior to revision see Koivurova and Kokko [15]. Substantively, the new provisions more clearly address environmental issues and public participation and require more precise assessments with respect to e.g. the rights of the Sami in relation to land use. Although without a clear legal frame, SIA are usually carried out in Finland by environmental consultation firms, universities and research institutions as a part of the Environmental Impact Assessment procedure required before the licensing process and subsequent activity can commence. They are also a financial requirement before a decision of investments can be made [13] (p. 40); [16] (pp. 25-30).

The environmental requirements for mining operations in Russia differ significantly from those in Sweden and Finland. Russia has substantial mineral deposits: over 60 large deposits of various types of valuable minerals exist on the Kola Peninsula alone. The underground and open pit mining industries are of huge importance for the economic growth and welfare development in the Murmansk region. The Strategy for Socio-Economic 
Development in the region is based on the development and modernization of exiting mining and metallurgical facilities, including additional ore-processing plants, and the opening of new mines. This implies increased anthropogenic impact in an area that is already heavily influenced by the concentration of industrial enterprises and other development factors (e.g. [17]) and moreover in a climate where environmental policy and law have often given way to economic goals [18].

The regulatory framework for mining operations in these three countries is complex and even unpredictable to some extent due to constant revision and inconsistent implementation. This article aims to perform a comparative analysis of these frameworks with particular focus on the licensing process, in order to identify their strengths and weaknesses with respect to their capacity to take into consideration social and, in particular, environmental aspects.

\section{Theoretical Framework and Methodology}

This study proceeds from the assumption that the corresponding regulatory frameworks in the examined countries do not encompass the instruments necessary to deal with modern mining. The legal system moreover constitutes the formal part of the overall institutional framework. All institutions are assumed to be relatively impervious to changes; they are path dependent. The concept of path dependence is widely used as an explanation as to why institutional change is difficult to implement. Why do, for instance, inefficient technical as well as social solutions persist over time? [19]. While the general notion of path dependence suggests simply that "history matters"; that choices and decisions made in the past affect the future span of possible, or feasible, choices [20], it can be used as a way to understand the impact of the system and assess the potential for action, i.e. which options are feasible and likely to penetrate the general institutional resistance to change. By unveiling path dependencies in the systems we can thus get an idea on what action is required for institutional change. Both the application of the law and the law itself may here constitute barriers.

Institutional path dependence occurs when an institution such as a law is created. The choices that lie behind that decision will have an inhibitory effect on the future; when a law is passed or a precedent case decided considerable efforts will be required to change the path, even if the law in time becomes less desirable [21]. Gupta et al. characterizes this inherent conservatism as both a weakness and a strength: "Institutions are agreements following long debate, and if these hard-won institutions would not survive until the next day, there would be little point in creating them.” [22] (p. 460). The legal system is a typical example of this: it is not meant to be easily amended as legal certainty is one of its most important aspects. The same forces that sustain institutions can however transform them. Laws and social structures can be modified, replaced and repealed. Change can occur rapidly as a consequence of a shift in power or sudden events, or gradually as a result of changing preferences and the understanding of, for example, the environment (e.g. [19]).

This study targets the formal institutional framework for mining and mining activities-in the form of the licensing process - in Sweden (as main study target), Finland and Russia (as comparative objects). With regard to document analysis, all legal studies here are qualitative studies based on positive analytical jurisprudence [23] [24]. This includes in-depth studies of the relevant legal sources in the respective legal systems, including not only legislation and case law, but also voluntary instruments like Social Impact Assessment that have a significant (and persistent) influence on the legal situation. The assessment regarding the potential use of novel instruments extends the methodology to include elements of normative and constructive jurisprudence, which allows for normative statements about how the law ought to be designed (cf. [23]). Moreover, policy analysis extends the document study to developing areas of regulation as well as to advice and implementation of legal requirements. The influx of EU law, which is of relevance for primarily Sweden and Finland, is addressed in connection with the study of the specific country.

\section{The Swedish Legal Framework for Mining Operations}

Sweden is one of the leading producers of minerals and metals in the EU and by far the biggest producer of iron ore: as much as 91 percent of the iron ore production in the EU comes from Swedish mines [25]. Swedish mining industry has moreover undergone a period of substantial growth, much due to the high demand for minerals from Asia. Pursuant to the latest Minerals Strategy [26], the Swedish Government wishes to seize the opportunities for increased but sustainable exploitation of mineral resources in order for the country to continue to evolve as the leading mining nation of the EU [26]. 
The right to mineral resources in Sweden is subject to special legislation. Establishing who originally holds the ownership, or user rights, to the mineral resource has always been of importance to the legislature. There are several theories on this matter, all aiming to balance the interest of extracting the mineral between three parties: the landowner, the state and the finder [4] (p. 17-18) ${ }^{1}$. Essentially three systems for governing the extraction of minerals can be distinguished: the landownership system, the concession system and the claim system [4] (pp. 51-52). The current Swedish mineral legislation, the Minerals Act, is usually described as a concession system with strong elements of claim rights [4] (p. 185).

The basis for all kinds of permit requirements is the need to control the activity from different perspectives, e.g. prevent environmental damage, facilitate development and ensure that different interests are considered. The licensing of mining activities is a rather complicated process that involves assessments by different authorities in accordance with several laws and regulations. The first step in the licensing process is to obtain an exploration permit. The main regulatory framework for the exploration permit is the Minerals Act. The purpose of this Act is primarily to enable the supply of essential metals and minerals and to determine who will have the right to exploit such resources. The permit, granted by the Mining Expectorate of Sweden, provides an exclusive right (also in relation to the landowner) for the permit holder to search for minerals within the designated area. A permit may be issued provided that the exploration is likely to lead to the discovery of concession minerals ${ }^{2}$ [27] (Ch. 2, s. 2). Exploration permits may not be granted contrary to general restrictions for e.g. nature reserves or National Parks or to land use planning instrument in the form of e.g. area protection or detail plans [27] (Ch. 2, s. 6). If the exploration activity will include test-mining ${ }^{3}$, it changes character and falls under the definition of an "environmentally hazardous activity" [28] (Ch. 9, s. 1), which entails that an environmental permit in accordance with the Environmental Code is required already at this stage ${ }^{4}$. In 2012, 86 percent of all applications, amounting to 183 new exploration permits, were approved. In addition to this 258 permits were extended [29] [30].

The second step in the licensing process is to apply for a mining concession, which is required in order to exploit the minerals. This kind of permit is also regulated in the Minerals Act. According to the Act, a concession should be granted for economically viable mineral deposits, provided that the "location and nature" of the deposit does not make it inappropriate to extract the minerals [27] (Ch. 5, s. 2). The mining concession defines who has the right to exploit minerals in the area, but does not give the right to begin the mining activity as this also requires an environmental permit. The mining concession is thus a necessary, but not sufficient, condition to conduct mining activities [32] (p. 217). In addition to the verification that the application complies with formal rules, the assessment for a mining concession also involves a reduced environmental impact assessment that includes an examination of the activity's compatibility with the resource management provisions in the Environmental Code [27] (Ch. 4, s. 2) $)^{5}$. These provisions are substantive rules for the overall management of land and water areas with the purpose of controlling the utilization of resources. In keeping with these provisions, areas of particular importance for certain activities, e.g. mining or reindeer herding, can be designated as national interest, which entails a certain protection against activities that may obstruct or hinder the designated use of the resource. It is considered necessary that the land use issue is decided already at the concession stage of the licensing process instead than in occasion of granting the (later) environmental permit. According to the government statements in the bill: "[i]t is doubtful whether any exploitation at all will be made if the person receiving mining concession may not be able to exploit the concession because it is determined at the (often years later) environmental permit assessment that the land should be used for some other purpose.” [32] (p. 215). This in fact implies that the authority responsible for the assessment of the compliance of the concession application with the resource management provisions speaks on its own behalf: the Mining Inspectorate is responsible both for the

\footnotetext{
${ }^{1}$ The landowner's interest is to benefit from the value of the mineral that $\mathrm{s} /$ he considers to be part of his land, the State has fiscal interests and the finder's interest lies in benefitting from the value of the resources that $s /$ he has put great efforts into finding and without whose efforts the mineral may never have been found [4] (pp. 17-18).

${ }^{2}$ Concession minerals include e.g. iron ore, copper, silver, nickel, gold, uranium and led [27] (Ch. 1, s. 1).

${ }^{3}$ The purpose of the activity is decisive for whether operations constitute test-mining or exploration. Test-mining may only be conducted to investigate the mineral with respect to its nature and the possibilities to process it [31].

${ }^{4}$ Note here however that the definition of an activity as environmentally hazardous does not automatically imply a requirement for permit, only that it may be subject to permit requirements.

${ }^{5}$ Excluded from this examination are thus the general environmental rules, including the precautionary principle and the BAT-requirements. The assessment of compliance with these rules is made within the scope of the overall environmental assessment. Also the consultation requirements of the EIA are limited; although it is suggested that the applicant consult with e.g. local and regional stakeholders, only consultation with the County Administrative Board is formally required at this stage in the licensing process.
} 
designation of national interests for mining and the balancing against other interests, influenced only by the County Administrative Board as the representative of the State. In connection with the land use assessment, the rules on Natura 2000 areas also apply [28] (Ch. 4 s. 8) and a special permit may be required if the planned activity may "significantly impact" such an area [28] (Ch. 7, s. 27-29). If the activity is not considered to be in conflict with other land use interests or in relation to spatial planning, and consent can thus be given by the County Administrative Board, the mining concession may be granted by the Mining Inspector ${ }^{6}$.

The environmental permit that, besides the mining concession, is necessary to commence the mining operation includes both a permit for environmentally hazardous activities and a permit for water operations. Environmental permits are also required for larger changes to existing operations, e.g. production increases [28] (Ch. 9, s. 6). The environmental permit application is decided by a Land and Environmental Court and must include an Environmental Impact Assessment together with a waste management plan, including a remediation strategy. Since mining activities are likely to have significant environmental impacts, a "full" EIA is required (cf. [33]) [34] (s. 3, Appendix 3), meaning that it must include information about the location, design and scope of the project as well as the measures planned to avoid adverse effects, alternative solutions and-not in the least-a non-technical summary [28] (Ch. 6, s. 7), [33] (Art. 5.3). The substantive assessment of the environmental impacts, e.g. the assessment of alternative solutions (for location, source of energy, etc.) is made on the basis of the general consideration rules in the Environmental Code, including the precautionary principle, the principle of substitution and the substantive requirements for the choice of location [28] (Ch. 2, s. 6). Consultation requirements are extended to include, besides the County Administrative Board and affected individuals, other government authorities, municipalities, the wider public, including Sami villages, and certain NGOs. The consultation must take place well before the application is made in order for the public to be able to influence the process at an early stage [35] (p. 282). The EIA plays an important role in the accomplishment of the Code's overall purpose, i.e. to promote sustainable development, and in the implementation of the principle of an integrated application of environmental law. According to this principle, all aspects of an activity (pollution, use of chemicals, processing, waste management etc.) should be assessed in context, including direct, indirect and even cumulative effects on the environment. All in all, "[t]he licensing process and supervisory practices should create incentives for the operator to be ahead of the legal requirements" [35] (p. 169, authors' translation, emphasis added). Although there are no formal barriers for preventing mining with the support of the rules of the Environmental Code, the environmental assessment is in practice "a matter of defining the frames for the activity" [36] (p. 58), meaning that, while the assessment shows every sign of a genuine permit process, it will still only result in conditions for the activity and not actually challenge the activity itself.

The principle of an integrated application of environmental law and, more precisely, the issue of the scope of the integrated environmental assessment, came forth in connection with the examination of a license for mining sought by the state-owned Swedish mining company $\mathrm{LKAB}^{7}$ in a process that ended up lasting several years. The facts of this case are as follows.

In May 2010, a license to open a mine at Gruvberget in the municipality of Svappavaara was granted by the then Environmental Court (now the Land and Environmental Court) [37]. The license allowed for the mining and processing of a certain amount of ore annually. The decision was appealed by the Swedish Environmental Protection Agency (SEPA) on the grounds that the assessment should have included both the new and the already existing activities in the area. According to SEPA, it was unclear what was included in the Court's assessment and what was covered by the permit, for instance with regard to the disposal of waste rock at the existing landfill and of groundwater and surface water at the reservoir. SEPA argued that "these issues have not been assessed in an appropriate manner and that there has been no comprehensive assessment of all of the licensed activities" [11] (p. 2). In short, the organization meant that is impossible to a make an assessment of the overall environmental impacts of the new mining operation and to regulate it in an appropriate manner if the interconnected activities, like the pelletizing plant, are not included in the assessment.

LKAB for its part had no objection to SEPA's argument for a more comprehensive and integrated assessment, but did not consider this to be the main issue in the case. Instead, the company argued that it was not only possible,

${ }^{6}$ In the following exceptional cases, the Mining Inspector should refer the issue of exploration concession to the Government: 1) the issue is of particular importance from the perspective of public interests (this has never occurred), or 2) if the Mining Inspector disagrees with the County Administrative Board's suggestion regarding the matter of land use (i.e. the application of Ch. 3-4 in the Environmental Code) [27] (Ch. 8, s. 2).

${ }^{7}$ Luossavaara-Kiirunavaara Limited Company. 
but also more suitable to regulate the different activities separately as it is common that a processing plant serves several mines, and "there has never been any doubt that these activities both can and should be regarded as independent units with respect to assessment and authorization” [11] (p. 5). The Environmental Court of Appeal began by noting that the main issue in the case was "whether the activity applied for is an independent activity that can be assessed and examined separately, as the company claims, or, if the existing plants have such links to the new activity that they should be regarded as one activity that should be considered jointly, as the Environmental Protection Agency alleges” [11] (p. 8). The Court acknowledged that the aim of the Environmental Code is to enable a comprehensive and integrated assessment of activities that impact the environment, e.g. by introducing legally binding principles and environmental consideration rules applicable to all environmentally impacting activities and measures. The activities in the mining case were considered by the Court to be both geographically and technically connected. For example, water from the new pit would be led to an existing reservoir not covered by the permit, additional noise pollution and air emissions would cause cumulative effects not covered by the permit and there was moreover no permit for the landfill for the waste rock. Hence, the Environmental Court of Appeal decided in December 2013 to repeal the (almost four years prior) ruling of the Environmental Court and reject the previous permit application. The company was then forced to submit a new license application covering the entire operations, including the processing plant.

The case suggests that there is uncertainty with regards to what should be included in the application for an environmental permit in accordance with the Environmental Code; different regulatory authorities may come to different conclusions on this matter. Notwithstanding the decision of the Court of Appeal in the referred case, the required scope of the environmental assessment in accordance with the Environmental Code is far from certain. What the Environmental Court of Appeal ultimately has established is that an application for license must be "complete", i.e., appropriately delimited and covering all environmental impacts that may be caused by the activity. In specific cases, this provides little guidance in how to determine the scope of the environmental assessment [38].

\subsection{Spatial Planning for Mining Activities}

The planning system constitutes an important part of the licensing process as a whole, both in terms environmental considerations and social aspects of the activity; by means of their planning powers, the municipal authorities play a decisive role in the advent of a mine and adjoining activities. In relation to mining activities, several planning instruments are relevant. Firstly, the overall land use and infrastructure within the borders of the municipality should be regulated in a comprehensive plan which sets out the direction for the long-term use of the physical environment as well as guides decisions on the use of land and water areas and the development and preservation of built-up areas [39] (Ch. 3, s. 2). Legally binding planning primarily takes the form of detail plans. For activities and constructions whose use will imply significant impact on the surroundings, the development of a detail plan is a requirement to commence the activity or construction. As it pertains to mining, a detail plan is typically required for the construction of warehouses, dressing plants and other buildings within the concession area. Also the planning instruments can be subjected to environmental assessments; if a proposal for a comprehensive plan or a detail plan is likely to have significant environmental impact a strategic environmental assessment must be made [39] (Ch. 3, s. 8). This is the case if, for instance, the comprehensive plan sets the framework for future development of e.g. large infrastructural activities [34] (s. 4).

\subsection{Conclusions from the Assessment of the Regulatory Framework in Sweden}

\subsubsection{The Environmental Code and the Minerals Act: Conflicting or Compatible Assessments?}

The starting point for the relationship between the Minerals Act and the Environmental Code is that the laws apply in parallel. The purpose of this is, among other things, to ensure that due consideration is shown to human health and the environment in the application of laws such as the Minerals Act. This implies, on the one hand, that anyone who conducts exploration or exploitation for minerals must comply with the rules in both laws. On the other hand, in keeping with the principle of lexspecialis, special law prevails over general law, meaning that the sectoral law will have priority if a conflict arises. With few exceptions, primarily regarding remediation of contaminated soil, the Minerals Act is not considered to include any provisions contrary to the Environmental Code [32] (p. 216), which is explained by the different purposes of the laws: while the Minerals Act aims primarily 
to regulate the relationship between mining actors and landowners (and others holding user rights), the provisions in the Environmental Code aim to promote a sustainable development, with environmental governance in the foreground. The main arguments for keeping the assessment for exploration permit and mining concession, including the land use assessment, separated from the overall environmental assessment, are that: 1) if the land use issue is not settled before mining concession is granted, the uncertainty regarding the necessary access to the land would hamper prospecting and investments; 2) the Minerals Act does not include sufficient requirements for environmental consideration to guarantee that the activity is conducted in an environmentally acceptable way. The purpose of the environmental assessment in accordance with the Code is therefore, as mentioned above, mainly to set conditions for the mining activity. However, there are other aspects that also need to be considered. From an interpretation perspective, the division into several laws entails that a permit assessment in accordance with a sectoral law does not necessarily reach the same result as an activity under the sole control of the Environmental Code (even if said law states that the general consideration rules in the Code apply). The holistic perspective on the environment and the impacts of environmentally hazardous activities that can be invoked as a result of the sustainability objective of the Environmental Code are missing or can be avoided if only parts of the Code is applicable in the assessment.

More in detail, it follows from Ch. 2 in the Environmental Code that the general consideration rules shall be considered in all matters that impact human health or the environment. Consequently the rules apply also to exploration and exploitation for minerals. In keeping with the principle of lexspecialis, only comparable rules in the Minerals Act would imply that those rules do not apply in the assessment of exploration permits or mining concessions. However, there are no such provisions in the Minerals Act. Hence, while the operator is indeed obliged to observe e.g. the precautionary principle, this will not be put to test in the permit and concession assessment. According to the preparatory works, the main reason for this is that mining concession is applied for in a stage when the specific environmental impacts of the activity are not fully known [32] (p. 218). At the stage of mining concession, the operation certainly involves a degree of uncertainty with respect to the specifics of the (future) environmental impacts. It can, however, be argued that not only should the applicant have sufficient knowledge with regards to both technical solutions and other precautionary measures to account for how the activity will be conducted with respect to human health and the environment also in the formal assessment, for example in the EIA accompanying the application for mining concession, but also that a complete EIA, with reservations for additional specifications in the assessment of the environmental permit, could enhance the quality of the participatory process by addressing potential issues as well as solutions at an early stage in the process.

The keeping of the since long existing legal arrangement where the land use issue is resolved within the framework of the mining concession, while all other environmentally related issues are dealt with in the assessment for environmental permit, points towards an institutional path dependence where the inherent resistance to change has led to a lack of systematics and perhaps also an insufficient implementation of the objective of sustainable economic, ecological and social development. The advent of the Environmental Code and the subsequent changes to the Minerals Act emerges as an attempt to incorporate environmental considerations in a system that ultimately has a very different purpose. This has also quite possibly increased the uncertainty, for example regarding the scope of the environmental assessment, for both those applying the law and those who have to abide by it.

\subsubsection{Issues of Efficiency and Predictability in the Licensing Process}

The design of the Swedish regulatory framework, where the assessment of the environmental impacts is largely done separately from the examination of exploration and mining concession under the Minerals Act, and to some extent also the spatial planning, opens up for subjective and varying assessments and provides extensive possibilities to appeal. The discretionary space enables for both political and private interests to affect the priority of conflicting interests. A case in point here is the fact that the Mining Inspectorate, in consultation with the County Administrative Board, is responsible for the assessment of conflicting land uses interests in accordance with the resource management provisions. If an area is of national interest for both mineral extraction and nature conservation, it is thus primarily the Mining Inspectorate who decides which land use interest that shall have priority.

The most important issue regarding the time frame for granting of applications is therefore probably the issue of predictability in terms of what should be considered to be part of the activity and thus what shall be included in the assessment. It is typically not the environmental requirements as such that pose a challenge for the mining 
companies, but the uncertainty in connection with the scope of the assessment for the environmental permit. The uncertainty regarding the extent of the environmental assessment applies also to the examination for mining concession as the EIA - that is reviewed by the County Administrative Board-is limited to environmental impacts in relation to the use of land and water, but the neither the extent of this assessment or the demarcation against the subsequent environmental review is completely clear. In the light of the rather weak guidance from both the legal text and case law, there is a risk that companies are too ambitious in the preparations of the EIA for the mining concession. Even if the EIA then can be re-used in the assessment for environmental permit, it is an inefficient solution.

It has been pointed out that the licensing process for mining operations in Sweden is unpredictable, unreasonably time consuming and thus inefficient (e.g. [9]). Beginning with the issue of the length of the licensing process, a more efficient process could possibly be accomplished by the introduction of time limits for the period between application and decision. This would likely imply that additional resources would have to be allocated to the relevant authorities. One potential drawback of a time limit is that in cases where the authorities have to set a deadline, it has to be connected to a specific time, e.g. the time of submission of a complete application. This in turn means that an additional decision has to be made, i.e. to determine whether the application is in fact complete and the deadline can start. If this proves difficult for the authority, the idea of time limits may have the opposite effect than the intended.

The efficiency of the licensing process is thus not only a function of what legal rules are in play, but also largely depends on the practices and approaches developed and applied by authorities and companies alongside the legal process. The institutional framework as a whole, including the general perception of the mining industry and the political support (or lack thereof) in terms of local ties for the activity, is of major importance for the possibilities to streamline the licensing process. Without local support for the mining operation, a flexible and otherwise well-functioning legal framework can still be used as a tool to hamper the process.

\section{The Legal Framework for Mining in Finland}

Finland has a long history of mining activity. Minerals such as nickel, zinc, copper, chrome, gold and iron ore, have formed a raw material base for the metal industry in the country since the $1600^{\text {th }}$ century [40]. The increasing demand for metal minerals since the beginning of the $2000 \mathrm{~s}$ has led to the opening of new mines as well as reopening of old ones, and many more projects are being considered and are under preparation in different stages. In 2012, a total of 50 mines and quarries covered by the Mining Act were operating in Finland. The main objective of the Finnish mineral sector is to be globally competitive, secure the supply of raw material, increase regional vitality and support a responsible use of natural resources. In the vision for 2050, presented in the Finnish Minerals Strategy, Finland is a global pioneer in the sustainable use of minerals, and the mineral sector is one of the foundations of the Finnish economy [41].

The right to exploit sub-surface minerals is mainly controlled by the Mining Act [42], which is applicable to metals, minerals, soapstone and marble. This act entered into force in 2011, with a Mining Ordinance [43] following one year later. Considering both that the transitional provisions of the Act state that pending matters must be handled in accordance with provisions in the previous Mining Act and the average time of licensing, is not yet possible to assess how the new law will be applied and to what extent environmental aspects will be safeguarded in the mining permit. It is also too early to assess how the new act functions in relation to the objective set out in section 1, i.e. "to promote mining and organize the use of areas required for it in a socially, economically and ecologically sustainable manner, giving particular attention to inter alia the impacts of activities on the environment and land use and the economic use of natural resources". A comparison of the legal texts reveals however that the new Mining Act addresses the question of environmental issues and public participation more widely than the previous act [44].

Both precautionary and remediation principles are valid for operations under the Act [42] (s. 6) and a new provision regarding collateral requirements for restoration, landscaping and other remediation measures are laid down as a complement to the collateral requirement under the Environmental Protection Act, which could enhance the opportunities for a holistic approach towards the environment [45] (p. 39-43). The new Mining Act can thus be said to meet some modern environmental law requirements by balancing the rights of different stakeholders and promoting ecological and social sustainability. It highlights the importance of considering environmental and human rights issues in ore prospecting and mining activities and therefore adds coherence and 
consistency to the overall natural resources law framework. It can however be argued that most of these issues were already covered by existing legislation concerning the environment and the Sámi parliament, and that the new Mining Act does not bring much new to the table besides the stricter requirements for cooperation in the application phase as well as a stronger link to the environmental legislation.

\subsection{The Licensing Process for Mining in Finland}

In order to commence mining activities in Finland, several permits involving several different laws are required. In accordance with the Mining Act, permits are required exploring and exploiting minerals. The Finnish system is still based on a claims system by which ownership to land does not give the owner right to exploit minerals on his/her land. Neither are the minerals considered to be owned by the state [46] (pp. 27 and 43), but the mining authority has jurisdiction to grant permits to explore and to exploit minerals in Finland. The scope for discretion for the permit authority is limited: if the application meets all criteria in the Mining Act and there are no legal impediments, the permit must be granted [47] (p. 60), [48] (p. 4). The formulation of the rules is therefore of most importance since it determines to what extent matters are decided on a case-to-case basis; the more precise rules, the less room for individual assessment. Pursuant to s. 48 of the Mining Act "a permit shall not be granted if the mining activity causes danger to public safety, causes highly significant detrimental environmental impacts, or substantially weakens the living conditions and industrial conditions of the locality, and said danger or impacts cannot be remedied through permit regulations". This rule thus stretches the limits of the assessment under the Mining Act towards considerations necessary for the environmental permit [12] (p. 426).

Also in Finland, mining exploration requires a permit. The exploration permit does however not give the permit holder the right to exploit the minerals, or to conduct any other mining activities, nor does it limit the land owner's right to use the area [42] (s.10). The restrictions imposed by the permit in relation to other land-uses are strictly connected to the needs of the permit holder to have access to the area for the exploration activities and do not include permanent measures. The exploration permit does however allow its holder to obtain a mining permit, which in turn provides a right to exploit the deposit [49] (p. 66). A mining permit is thus required for the development of the mine and the mining operation [42] (s. 16). The Finnish Safety and Chemicals Agency (TUKES) is the authority responsible for permit applications under the Mining Act ${ }^{8}$. A mining permit allows for the extraction of the mineral resources found in the designated area, as well as of the organic and non-organic surface material, waste rock and tailings that arise as a bi-product of the mining activity [42] (s. 17). The operator of the mine must see to that the mining activity does not imply nuisance for human health or jeopardizes general safety or causes significant nuisance for public or private interests, including such violation of public or private interest that can be reasonably avoided in consideration of the overall costs of the mining operation [42] (s. 18). This applies also to the area around the mine, implying that roads, transport facilities, power lines, etc. must be located and operated a way that does not cause nuisance to human health or the environment or endangers general safety [42] (s. 19). As for participation, all permits under the Mining Act require a public hearing.

Under the former Mining Act (where rights similar to those of an exploration permit were given though claims) the lack of awareness among both the general public and stakeholders in Finland on the difference between an exploration permit and a mining permit resulted in a number of legal proceedings. The complaints related often to the environmental impacts of the activity, even though exploration activities are not comparable to actual mining activities ${ }^{9}$. In the new Mining Act, the contents of these rights are basically the same, but the Act requires stronger public hearing already before the exploration permit can be granted. It is however too early to say if this will result in better information exchange and increase the publics' understanding of the different stages in the mining process. Ideally, a public hearing aims not only to information dissemination, but also to enhance the possibilities for mutual understanding of the decisions, the process and its basis [50] (p. 183), [51]. If done successfully, the interaction between potential operators and the public may also reduce the number of complaints founded on an inaccurate interpretation of the Mining Act.

The set of environmental assessments required in the licensing process is also rather extensive. While exploration work typically does not require a formal EIA, it can be necessary to make other assessments, for instance

\footnotetext{
${ }^{8}$ For permits concerning uranium or thorium mining, the Nuclear Energy Act applies and the permit authority is the Finnish Government [52].

${ }^{9}$ Soudunsaari observed that in complex licensing processes with multiple hearings and permits, the public often confuses the different stages in the process [53] (p. 29).
} 
if the exploration will take place in a Natura 2000 area or in other conservation sites ${ }^{10}$. Thus, both the Nature Conservation Act and the Environmental Protection Act must be observed already in the exploration phase. For the mining permit, an EIA is mandatory, and an environmental permit in accordance with s. 27 is typically required.

The Environmental Protection Act is based on the general principle of best environmental practice and the principle of caution and care [56] (s. 20). The list of applicable general principles was more extensive before the reform of the Act and included the principles of pollution prevention, Best Available Technique (BAT) and the polluter pays principle (PPP). These principles still apply but are now expressed in the form of a more extensive set of principles and obligations [56] (Ch. 2). The new provisions have also a wider scope as e.g. energy efficiency measures are a prerequisite for an environmental permit. This issue in particular could previously be governed instead by conditions of the permit. A review of the environmental permits for mining operations under the previous Environmental Protection Act shows that permit conditions have increased significantly. For large operations it was not unusual for the permit to hold $80-100$ binding conditions ${ }^{11}$ where may were just a repetition of the wording of the Environmental Protection Act. As a general rule though the operator must know the contents of all applicable laws and adhere to them even if not duplicated in the permit text. The compliance with the law was thus not as effective as desired and the revision of the Environmental Protection Act, where the requirements and obligations are posed in a clearer and more general manner, is an attempt to address this problem.

All in all, however, the reform of the Environmental Protection Act does not significantly change the permit requirements for mining operations. The operation must be conducted in accordance with any requirements that can be imposed on the operator on the basis of the fundamental principles of environmental law. This means that the operator is required to take both preventive and reparative measures to hinder or counteract adverse effects of the activity, including accidents. A combination of various methods and measures must be used in this context, which means that e.g. work methods, raw materials and fuel shall be selected to provide appropriate and costeffective means to prevent pollution. Best available technique must be used throughout the whole operation, including adjoining activities as well as in the process of closing the mine.

The EIA procedure in Finland is regulated in a separate Act [57], which is based on the EU EIA Directive [33]. Mining operations of a certain size are listed as activities that always require an EIA [58] and may also be required for smaller activities if considered necessary with regards to the characteristics of the planned operation, for instance if the area is already heavily exploited and the cumulative environmental impacts then risk exceeding limit values [58] (s. 7). The environmental impacts of the planned project shall be assessed well in time before any action that may affect the environment is taken, and at the very latest, before any authoritative decisions regarding the implementation of the project are made [13]. Consequently, the EIA must be included in the permit application.

In Finland, the EIA process includes two stages. The first part is the so called assessment procedure in which different possibilities and alternatives for the operation, including constructions, power lines, traffic etc., are presented and compared in order to find the most suitable alternative from an ecological and economic perspective and eliminate inappropriate options. A zero alternative must always be presented to illustrate the scope and implications of the different options. Public participation is an essential part of the EIA process and the requirement to exchange information about the potential impacts of the planned operation is imperative. The assessment procedure includes a public hearing where the coordinating authority, the Centre for Economic Development, Transport and the Environment, must request statements from other authorities and municipalities affected by the development before the hearing [57] (s. 8 a). The second part of the EIA process is referred to as the reporting stage. In this stage the project developer must prepare a more detailed assessment report, based on the

\footnotetext{
${ }^{10}$ If the mining operation is likely to have a significant impact on a Natura 2000 area, a special procedure based on the rules in the Nature Conservation Act, which in turn is based on the EU Habitats Directive, is required. The limits for allowed deterioration set out by the Nature Conservation Act shall be interpreted in the light of the Directive and any uncertainties with regard to the environmental impacts of the planned operation shall be balanced against the precautionary principle [54]. If the land-use operations imply notable deterioration for protected species or nature values of the Natura 2000 network, permit should not be granted unless it is deemed essential from the point of view of public interests [55] (p. 14).

${ }^{11}$ For example permit No. 79/2014/1 for extending the operations of Kevitsa has over 80 conditions; permit No. 33/2013/1 for Tipas, almost 110 conditions; the revised permit No. 36/2014/1 for Talvivaara, almost 120 conditions; and the revised permit for Suurikuusikko (No. 72/2014/1), almost 80 conditions. This can be compared with the first environmental permit in 2001 (No. 69/02/1), which has less than 50 conditions and the permit for the Kemi chromite mine (No. 77/02/1), which has approximately 30 conditions.
} 
knowledge and statements gathered through the first part of the process. This stage also includes a public hearing; statements are requested from affected parties [57] (s. 11-11a). The EIA process is concluded when the coordinating authority receives the assessment report and gives a statement of its adequacy [57] (s. 12). The main purpose of the EIA process is to gather information and to plan; no factual decisions are made at this point. For this reason, appeals cannot be based on the contents of the EIA, but rather relate to is in adequacy or deficiency of the assessment [57] (s. 17).

\subsection{The Role of Spatial Planning for Mining Operations in Finland}

Since mining operations require access to land areas and typically involve the construction of various buildings, land use permits in the form of planning permissions and building easements are required in keeping with the Land Use and Building Act [59]. The planning system is hierarchical and based on national land use objectives (NLO) which ensure that issues of national interest are taken into account in land use planning and in the activities of the government authorities [59] (Ch. 1, s. 3). The national land use objectives, together with the regional and local master plans, thus direct the legally binding and more detailed local plans.

A (large) mining project can involve all stages of planning; from the necessity to relate to the national land use objectives, e.g. regarding environmental protection and energy production, to the building permit required for the actual mine and its adjoining activities. However, the precise planning instruments required for a particular mining project depends on the characteristics of the project. According to the Mining Act, the larger mining area, i.e. including the area required for the adjoining activities, must be investigated in relation to other land uses; the mining operation shall be based on a plan with legal effects under the Land Use and Building Act or, with respect to the impact of the mining operation, be "otherwise sufficiently investigated" [59] (Ch. 6, s. 47). Taking part in zoning procedures is recommendable for the representatives of mining companies, even if it not required for mining sites to be zoned in land use planning. Although Finnish law does not provide veto rights for local authorities in relation to mining, the municipality may still invoke valid reasons to oppose the granting of a permit: pending land use planning for a purpose which would be impeded by the mining operation, a planned land use which is incompatible with mining activities, or if the area holds special ecological or cultural values [13] (p. 29), [12] (p. 424).

\subsection{Conclusions from the Assessment of the Regulatory Framework in Finland}

The regulatory framework in Finland entails that environmental assessments are primarily made via the EIA instrument in connection with the licensing of the mining operations as well as to some extent also via the physical planning, where other land use interests, including conservation interests, can be brought forth. The potential scope of the environmental assessment thus appears to be rather extensive. The Mining Act explicitly requires that human health, safety and environmental impacts are taken into account as a precondition for the granting of a mining permit. According to TUKES, a permit shall "not be granted if the mining operation presents a danger to public safety, cause significant adverse environmental effects or significantly impairs the built environment and nutrient conditions in the locality and the aforementioned danger or the effect cannot be eliminated by state regulations" [60]. The licensing process also entails, several hearings involving both authorities and stakeholders and the general public.

The legal framework for mining activities in Finland thus points towards a balancing of different land use interests, where there is room for environmental aspects to be considered throughout the entire licensing process. While this per se does not prevent environmental deterioration, it is necessary to prevent activities whose environmental effects are too severe and to ensure that necessary precautions can be required. Finally, the extension of the requirements for public hearings under the new Mining Act will potentially help to make the legal requirements and environmental impacts of different mining-related activities more understandable and thus allow for more accurate appeals.

\section{The Legal Framework for Mining in Russia}

Russia is one of the world's richest countries in terms of natural resource assets, and not in the least subsoil resources play a very important role for the Russian economy. The privatization process that large parts of the Russian economy underwent as part of the transition to market economy included the distribution of rights to 
mineral resources. According to the Constitution of the Russian Federation: "Land and other natural resources may be in private, state, municipal and other forms of ownership.” [61] (Ch. 1, Art. 9). In keeping with this new legislation, aimed at modernizing the legal framework for the management and use of subsoil natural resources, as well as the licensing process, was adopted in the form of the 1992 Subsoil Lawof the Russian Federation.

However, already in the beginning of the 2000s, serious shortcomings of the system were observed [62]-[64]. Kotov [62] noted, for example, that mining operations were still carried out without a permit and that about 30 percent of the licensees did not comply with the legal demands for subsurface mining ${ }^{12}$. Overall, the system was seen as characterised by major flaws and uncertainties, both from the point of view of the authorities and of the licensees, as well as from the state [63]. Suggestions for improvement were put forward by government agencies, including measures such as verification of license holder's compliance with legal requirements, punishment for violation of license conditions and enhanced possibilities and grounds to revoke the licenses [62]. The Putin administration accepted responsibility and promoted a transition from the existing system, based on administrative licensing, to a system based on contracts and an abolishment of the so called "two-key principle"13 [63]. However, after a lengthy and very complicated process where a proposal for a new subsoil law was debated back and forth between different parties whose interests were rarely compatible, "high-ranking officials came to the conclusion that amendments to the existing legislation were preferable to the adoption of a new law." [63] (p. 1408). In the end, no new law was adopted. Instead, the 1992 Subsoil Law was amended e.g. to include restrictions for the granting of subsoil rights with regard to "plots of federal significance" (also referred to as "strategic fields") in favour of Russian corporations (cf. [65] Art. 2-1, 2.2, 9, 13.1 and 17.1), thus strengthening the role of the State in the exploitation of resources.

\subsection{The Subsoil Law}

The exploration and production of subsoil resources, including minerals, in Russia is based on a licensing regime. The main objective of the regulation of subsoil use is to: "ensure the reproduction of mineral resources and its sustainable use and the protection of natural resources for present and future generations of the Russian Federation.” [65] (Art. 29). The definition of mineral resources in Russia is somewhat different from the terminology commonly used in literature [62]. According to the Subsoil Law, mineral resources are any component of the subsoil, which is defined as the part of the earth's crust that is situated under the layer of soil or under water bodies, extending down to the furthest point where extraction is possible, including ores, oil and natural gas [62] [65]. Furthermore, under Russian law, minerals are divided in two main categories: common resources and other resources. A subgroup of "strategic resources" that includes oil, gas, platinum, uranium etc. is defined under the "other resources" category.

The right to the subsoil resources in Russia belongs to both the federation and to the regions; according to Art. 72, 1-c in the Constitution of the Russian Federation "issues of possession, use and disposal of land, subsoil, water and other natural resources" are included in the joint jurisdiction of the Russian Federation and the subjects thereof [61] [65] (Art. 1-2). However, the user of the subsoil resources can be any actor, including foreign companies, and the allocation of the user rights is based on joint decisions by federal and regional authorities [62]. The exclusive right to use the subsoil resources for exploration and processing of minerals is established via a licensing procedure in accordance with the Subsoil Law [65] (Art. 6). The licensing system is a uniform procedure administrated by the Federal Authority for administration of the State fund of Subsoil resources [65] (Art. 16) with the objective to provide for: the implementation of state programmes for the development of the mining industry and the raw material base; the consideration of social, economic, environmental and other interests; the development of market relations and anti-monopoly policy; and the necessary guarantees for licensees of the mineral rights [65] (Art. 15). The legislation distinguishes three types of subsoil use licenses with respect to the development of natural resources [66]:

1) Exploration license, which allows for the exploration of subsoil resources and is granted without a tendering or auctioning procedure. The exploration license is granted for a maximum of five years and does not allow for production;

2) Production license, which is issued for explored resources (known deposits) and awarded by a tendering or

\footnotetext{
12“"[L]icensing procedures are constantly violated in interests of license-holders; license-holders are not held accountable for license conditions; sanction mechanisms do not function, or are not applied to violators; and charges for mineral resource use are not paid.” [50] (p. 9).

${ }^{13}$ Under the "two-key principle" it was necessary to obtain the approval of both the regional and federal authorities before gaining a license.
} 
auctioning procedure for as long as necessary for a complete exploitation of the deposit;

3) Combined license, which is issued for known deposits that require substantial additional exploration. The combined license is also awarded by a tendering or auctioning procedure.

The license is defined as a document that certifies the right of the owner to use the subsoil within certain specified limits [65] (Art. 11). The subsoil user rights may be terminated if, for example, the permit conditions are breached, or in the event of e.g. immediate danger to life and health of the people working or living in the impact area of the activity [65] (Art. 20).

\subsection{Obligations of the Licensee}

The subsoil user has then certain rights and responsibilities with regard to the activities provided by the license.

According to the fundamental rights and obligations of the user, users and other legal entities as well as private persons involved in the use of the subsoil is for example under duty to follow the main requirements related to rational utilization and conservation of the earth resources [65] (Art. 22 and 23). The development of mineral deposits shall moreover be fulfilled in obedience with certain technical standards, i.e. in keeping with approved engineering projects [65] (Art. 23.2) which should be agreed by a special committee prior to approval. The committee includes representatives of the State mining supervision and executive authorities in the field of environmental protection. The procedure of preparation, agreement and approval of engineering projects related to the utilization of subsoil plots is established by the Russian Federation Government according to mineral category and type of subsoil use. During the processing of minerals, the subsoil user must e.g. provide for strict compliance with technological schemes for mineral processing, which controls the minerals distribution at different stages of processing as well as the degree of their extraction from mineral raw resources, with the aim of providing for a rational and integrated extraction of commercial elements [65] (Art. 23.3).

\subsection{Environmental Aspects in the Licensing Process}

According to the Subsoil Law, the relationship between the use and protection of the environment arising out of the use of the subsoil is regulated by relevant sectoral legislation [65] (Art. 1.5). Hence, the assignment of land areas, forest areas and water objects for activities related to the subsoil use, as well as their withdrawal from such use, are also regulated by land, forest and water legislation [65] (Art. 25). The responsibility for controlling the activity's compliance with the environmental legislation, as well as for supervising the activity, falls on the Ministry of Environment, who is also responsible for the overall protection of the subsoil resources. The assessment of the potential environmental impacts of the mining operation is made in the planning stage of the operation and involves several Acts, most notably the Law on Environmental Protection and the Environmental Impact Assessment Act. These include substantive provisions in relation to the environment and prescribe e.g. precautionary measures and emission limitations or environmental quality standards.

The Law on Environmental Protection [67] "lays down a legal foundation for state policy in the field of environmental protection to ensure a balanced solution for socio-economic tasks, the preservation of a favourable environment, biological diversity and natural resources" and "governs in the field of interaction of society and nature occurring in economic and other activities that affect the natural environment" (preamble). The law is applicable for activities that affect the environment, including the exploration and exploitation of the sub-soil, for example in order to extract mineral resources [67] (Art. 2.5) and in accordance with Article 4.1, sub-soil resources in the Russian territory shall be protected from depletion and degradation as well as from other adverse effects resulting from the activity. The law requires the performance of an environmental impact assessment in accordance with the Law on ecological expertise [68] prior to the commencement of certain environmentally hazardous activities.

The prescribed EIA process includes three stages. The first step is the preliminary assessment, which includes collecting and documenting data including a general description of the planned activity and its objective, possible alternatives, localization, compliance with regional and economical plans and programmes, the state of the environment in the area and measures to reduce or prevent the environmental impacts. The preliminary assessment is the basis for the Terms of Reference (ToR) for the EIA. The ToR sets out e.g. data on the operator, main objectives for the EIA and a plan for public consultations. The ToR should be made available for all participants in the EIA process, including the general public. During the second step of the EIA process, alternatives to the proposed project, including the zero-alternative, are studied. Also, the environmental, social and economic im- 
pact of the different alternatives and the territory in question is analysed in terms of e.g. existing anthropogenic load. Programmes for monitoring and control of the implementation of the activity are also developed during this stage. The studies in the second phase form the basis for the EIA, which is put up for review to the public who may comment and make suggestions before the EIA is submitted for a state expert review. As a third step of the process, a final version of the EIA, where due consideration has been paid to comments, suggestions and information received in the process, is produced and submitted for assessment to the responsible authority. The general public also has a right to register and organise a public (independent) environmental expert review of the planned activity.

However, as a result of "disassembling” of Russian environmental law, the Law on ecological expertise has lost its universal meaning during the last decade. First, the possibility to confer legitimacy to scientific demands has been revoked, and secondly, the law only applies to a restricted number of projects, for example, if the project is located on the continental shelf or in conservation areas. The overwhelming majority of all mining projects are therefore no longer covered by the provisions [69]. Still, all mining projects have to pass the assessment by the State, which also includes environmental requirements, but these are not necessarily in compliance with the EIA regulations pursuant to the Law on ecological expertise. In practice, however, many companies follow the EIA regulations, but there are exceptions: for example the ZAO North Western Phosphorous Company (SZFK), took advantage of the indulgence suggested by the law and escaped public hearings, but to the price of lost goodwill [70].

\subsection{Conclusions from the Assessment of the Regulatory Framework in Russia}

While the sustainable use of subsoil resources and environmental protection are indeed mentioned in the legal framework for subsoil use under Russian legislation, the extent to which environmental considerations are actually made is very difficult to assess. Environmental impact assessments are not mandatory for mining operations and although environmental law principles as well as substantive rules for the protection of the environment apply to the extraction of minerals, there are serious indications suggesting that the space for neglecting not only environmental requirements, but also other aspects of the license, is significant. The central discussions regarding the subsoil legislation over the last two decades have revolved around issues connected to property rights, resource rights, market mechanisms and even public involvement, rather than environmental impacts of the subsoil use.

The urgent problems of the mining industry and suggestions for reform and supplement of the mining legislation are regarded in a series of articles at the past $\mathrm{VII}^{\mathrm{th}}$ geological congress, at conferences and Parliament hearings and in various related meetings. The suggestions aim to raise the efficiency of the subsoil resource management in the Russian Federation. The possibility of establishing a Centre for analysis, monitoring and preparation of draft regulations for improving the subsoil resource management system is currently under discussion. Two thirds of the specialists in the Working Group of the suggested Centre would consist of mining industry specialists (i.e. geologists, miners, economists and lawyers). Adaptation of the subsoil legislation to contemporary mining conditions is expected to reduce the existing limitations. Nevertheless, work to design a coherent Mining Code has also been initiated [71].

\section{A Comparison of the Licensing Process in Sweden, Finland and Russia}

The examination of the regulatory frameworks for mining operations in the three countries exhibits both similarities and differences with regard to both the licensing process and the scope of the environmental assessment. The comparison is based on the main features of the licensing process and the strengths and weaknesses hereof with respect to the capacity to take into consideration, in particular, environmental issues, but also social and economic aspects of the mining operation.

A very important aspect of the licensing process is the issue of land-use. For regular assessments of environmentally hazardous activities in Sweden, this issue is settled in the process for environmental permit, but for mining activities the issue is determined already in the decision for mining concession. This essentially means the assessment of what is the most suitable use of the areas with regard to "their nature and situation and of existing needs" [28] (Ch. 3, s. 1), is thus determined by the Mining Inspectorate, i.e. the agency whose main task is to handle matters relating to the exploration and extraction of minerals under the Minerals Act, and not by the Land and Environment Court, which is usually the body that has to decide on matters relating to more intrusive 
environmental hazardous activities. Securing the rights to the land is of course crucial for the possibility to grant an expedient mining concession and it may therefore be deemed necessary to decide on the matter in connection with that examination. It is also possible for the Mining Inspectorate to refuse a mining concession with reference to the environmental impact in terms of land use, for example if the solution for ground transport is likely to cause excessive damage or significant impact on other land uses. In determining the mining concession, it is however not considered appropriate to decide on other environmentally related issues, such as emission levels and precautionary measures, since the extent of the environmental impacts of the activity is not fully known. Hence, these matters are handled at later stage in the licensing process, namely in the examination for environmental permit. Unlike the mining concession, which aims primarily to ensure ownership of the deposit, the purpose of the environmental assessment is to make sure that the activity does not cause (irreversible) harm to the environment. In Finland, where the overall process is similar to the Swedish, i.e. with separate permits for exploration, mining and environmental requirements; environmental consideration needs to be taken into consideration also in the assessment for mining permit; significant nuisance for e.g. the environment shall be prevented.

The basis for the environmental assessment is the EIA, which is prepared by the operator and subject to consultation with the public, stakeholders, NGOs and government agencies. In both Sweden and Finland, the regulatory framework for EIA, including the process, is based on the EU EIA Directive. The Swedish implementation of the EIA process departs from the Finnish insofar that the Swedish EIA provisions are part of the Environmental Code, whereas the EIA process in Finland is regulated in an own law and includes two hearings as opposed to, as a main rule, one in Sweden. The requirements in terms of the contents of the EIA are also more extensive in Finland than in Sweden. In Sweden, the contents of the EIA are clearly linked to-and controlled by - the general consideration rules and the resource management provisions of the Environmental Code. In Russia, the formal requirements for EIA are similar to the Swedish and Finnish.

Regarding the scope of the environmental assessment, Swedish environmental law undoubtedly requires an integrated examination of the environmental impacts of the activity, although it is not entirely clear what this entails in terms of e.g. geographical limits and in relation to existing activities and potential cumulative effects. While it is theoretically possible to stop the mining operation on account of its environmental impacts, this was not the intention of the legislator, and consequently the function of the environmental assessment is basically only to set conditions for the activity.

The examination of the Swedish licensing process for mining operations thus reveals a system that is meant to be efficient and comprehensive, but that has some flaws primarily with regards to the systematics of the legal framework. The main weakness of the system is probably the discrepancy between, on the one hand, the explicit exploitation purpose of the Minerals Act and, on the other hand, the sustainability objective that directs the implementation of the Environmental Code. This does not mean that mining per se is incompatible with sustainable development, but rather that the system of laws that govern the licensing process have conflicting purposes. It also implies that, in the end, the license is granted; it is only a matter of time. Despite the claims of a horizontal process with parallel application, the Swedish licensing system for mining operations has strong hierarchical tendencies.

In Finland, the recent revisions of the Mining Act and the Environmental Protection Act appear to have enhanced the coherence between the different laws involved in the licensing process for mining operations. The inclusion of environmental aspects in the Mining Act means that the Act no longer merely aims to set operational conditions for the industry, but also attempts to weigh the interest to explore and exploit minerals against other interests, although — self-evidently - the main purpose of the Act is still to control the mining industry and its development. The changes to the Environmental Protection Act may also prove to be important, not least from an efficiency point of view, although they do not alter the environmental requirements for extracting industries. The amendment is a result of experiences and lessons learned from the industry, and may thus represent the kind of grounded institutional change necessary to counteract path dependence.

From an efficiency point of view, both the Swedish and the Finnish licensing process is relatively unpredictable with regards to not only time-consumption from application to final decision, which is partly a result of the numerous permits required and the adjoining possibilities of appeal, but also in relation to the conditions under the operation will be permitted, a consequence of the case-to-case assessment-model. It remains to be seen if the amendments made in the Finnish system will have some implications with regard to this

In Russia, the system appears to be a rather modern regulatory framework with declarations for sustainable resource management and several environmental laws, including the EIA regulations, which are claimed to be 
applicable to mining operations. In practice however, significant weaknesses can be detected: the declarative character of Russian environmental law is not followed up by substantive rules and both the application and the implementation seems to suggest that proper environmental concerns cannot be guaranteed.

\section{Concluding Remarks}

This paper examines the licensing process for mining operations in three countries: Sweden, Finland and Russia. The study is based on the premise that the licensing process is an important factor for the control of the use of natural resources. The existence of and requirements on environmental considerations in this process ideally include reflections on sustainable resource management. While mining in general can be considered ecologically unsustainable since it entails exploitation of non-renewable natural resources, the activity can also improve economic and social sustainability e.g. by increasing employment and improve local community development. A license to conduct environmentally hazardous activities implies that the operator receives a permit to commence or modify an activity that per definition may cause harm to human health or the environment. It is therefore crucial that the environmental impacts of the activity are both assessed in advance and thereafter controlled to ensure compliance with basic environmental requirements [38] and that the environmental assessment implies striking a balance between exploitation and preservation interests with sustainable resource management as the primary objective. Over the past two decades, efforts to implement both the overall objective of sustainable use of natural resources and substantive rules for the assessment and control of environmental impact, e.g. precautionary requirements and EIA, have been made in all three countries.

The analysis of the scope of the environmental considerations in the licensing process for mining operations shows that there are substantial differences between the countries in relation to the interpretation of the legal requirements and the factual implementation. This may at least partly be attributed to the fact that the legal framework only constitutes a part of an overall institutional framework that is typically characterized by path dependence, making implementation strongly susceptible by existing policy and practice. The institutional environment is hence crucial both for the feasibility of implementing new governance systems and objectives, as well as in terms of assessing the time-frame for specific collaboration [64]. The institutions' relatively enduring character also implies that, even if the formal rules are changed, change in the structures of human behaviour is typically a gradual and long-term process (e.g. [72]). Translated into environmental considerations in the course of the licensing of mining activities, this means it can prove rather difficult to implement e.g. principles of precaution and environmental responsibility in a licensing process with the primary aim of facilitating exploitation, good intentions aside.

Institutional change is thus a long-term process, and one that rarely involves radical transformation; traces from previous settings typically remain and contribute to the path dependence of the system as a whole. This is visible in all three countries examined in this paper, but perhaps mostly in the Russian context where the current institutional framework governing the use of the Russian natural resources still shares some of the features from the previous (Soviet) period, not least in terms of power distribution. Beare notes that "although primary [environmental] legislation is recent, the mindset of the regulators is rooted in legislation and regulation of the 1980s." [73] (p. 2). Hence, notwithstanding the fact that the institutional framework in Russia has undergone a significant transition and that most prioritized environmental issues are now addressed by the environmental regulation, the institutional path dependence constitutes a major obstacle to effective changes. While Russian environmental legislation indeed proclaims to aim at striking a balance between ecological and economic interests, and recognized both individuals and companies a "right" to a favourable environment, serious deficits with regards to implementation and enforcement of (sometimes unrealistic) substantive rules are exhibited. In addition, the authorities are not knowledgeable on how to apply environmental legislation, which is made more complicated by the large number of environmental permits that need to be obtained within a system where the decision-making powers are far from clear [73] [74]. It seems clear that the law develops in parallel to social and economic development, and that change in the formal institutional framework needs to be grounded in the system as a whole to be effective, i.e. for the changes to actually have an impact. The implementation of the relatively strict Russian environmental legislation from the 1990s failed mainly as a result of a strong institutional environment with embedded norms aiming to maximize resource exploitation. Attempts to restore the partially dismantled environmental legal system in Russia can now be observed, for example through clarifications in terms of the scope of the environmental law, introduced by e.g. Federal Law No. 219-FZ [75]. 
Russia is however not the only country that exhibits signs of institutional path dependence. Also in Sweden, where a transition to a more sustainable resource management, characterised by a rational exploitation of natural resources, has largely been implemented, the licensing process is still basically ruled by the exploitation-oriented Minerals Act. There is thus still a risk that the careful balancing of different land use interests, based on precautionary and participatory principles and required by the environmental legislation, is overlooked as a result of the design of a licensing system under which the environmental assessment is neither coherent nor clear. In this context, the explicit reference to human health, safety and environmental impacts in the Finnish Mining Act, can be seen as representing a more nuanced stance in terms of the importance attached to the environmental interests, although it remains to be seen to what extent this actually has an impact on the manner in whichmining operations are planned and carried out.

\section{Acknowledgements}

This paper is written within the SUMILCERE research programme on Sustainable Mining, Local Communities and Environmental Regulation. Financial support from the Kolarctic ENPI CBC programme is gratefully acknowledged, and so is also the interpreter Tatiana Malysheva's invaluable help with translations.

\section{References}

[1] Digman, H. (1953) Svensk gruvrätt. P.A. Nordstedt \& Söners Förlag, Stockholm.

[2] Delin, L. (1996) Minerallagen och kontinentalsockellagen. Nordstedts Juridik AB, Stockholm.

[3] Delin, L. (1977) Gruvlagstiftningen. P.A. Nordstedt \& Söners Förlag, Stockholm.

[4] Bäckström, L. (2012) Rätten till mineral. En studie om befogenheter och legala inskränkningar i äganderätten till fastighetens beståndsdelar. Licentatethesis, Luleå University of Technology, Luleå.

[5] Liedholm-Johnson, E. (2010) Mineral Rights. Legal System Governing Exploration and Exploitation. Doctoral Dissertation, KTH Royal Institute of Technology, Stockholm.

[6] Pettersson, M. (2008) Renewable Energy and the Function of Law. A Comparative Study of Legal Rules Related to the Planning, Installation and Operation of Windmills. Doctoral Dissertation, Luleå University of Technology, Luleå.

[7] Pettersson, M., Ek, K., Söderholm, K. and Söderholm, P. (2010) Wind Power Planning and Permitting: Comparative Perspectives from the Nordic Countries. Renewable and Sustainable Energy Reviews, 14, 3116-3123. http://dx.doi.org/10.1016/j.rser.2010.07.008

[8] Söderholm, P. and Pettersson, M. (2011) Offshore Wind Power Policy and Planning in Sweden. Energy Policy, 39, 518-525. http://dx.doi.org/10.1016/j.enpol.2010.05.065

[9] Aaro, L.-E., Ferbe, A., Evrell, L., Fahlberg, C., Sundelin, B., Sterte, J., Waplan, K.-A., Bennerdt, S., Bengtsson, U. and Hedlin, J. (2012) Debatt: Ge gruvorna chansen. Dagens Industri, 30 januari 2012.

[10] Söderholm, P., Michanek, G., Pettersson, M. and Söderholm, K. (2009) Tillståndsprocesser och planering för ny elproduktion: Sverige i ett internationellt perspektiv. ElforskReport 09:12, Stockholm.

[11] Judgement by the Swedish Environmental Court of Appeal in Case 4866-10.

[12] Pölönen, I. (2013) Ympäristönäkökohtien ja paikallisten toimijoiden asema kaivoslain mukaisessa lupaharkinnassa. Lakimies, 3, 414-435.

[13] Kokko, K., Oksanen, A., Hast, S., Heikkinen, H.I., Hentilä, H.L., Jokinen, M., Komu, T., Kunnari, M., Lépy, É., Soudunsaari, L., Suikkanen, A. and Suopajärvi, L. (2014) Sound Mining in the North-A Guide to Environmental Regulation and Best Practices Supporting Social Sustainability. Research Report, Multiprint Oy, Oulu.

[14] Government Offices of Finland, Government Bill, 273/2009.

[15] Koivurova, T. and Kokko, K. (2008) Proposal for a New Mining Act-Old or Fresh Wine in a New Bottle? In: Koivurova, T. and Stepien, A., Eds., Reforming Mining Law in a Changing World: With Special Reference to Finland, Annual Report of the Northern Institute for Environmental and Minority Law (NIEM), Arctic Centre University of Lapland, Finland, 206-212.

[16] Suopajärvi, L. (2013) Social Impact Assessment in Mining Projects in Northern Finland: Comparing Practice to Theory. Environmental Impact Assessment Review, 42, 25-30. http://dx.doi.org/10.1016/j.eiar.2013.04.003

[17] Rigina, O. (2001) Environmental Impact Assessment of the Mining and Concentration Activities in the Kola Peninsula, Russia by Multidate Remote Sensing. Environmental Monitoring and Assessment, 75, 11-31.

[18] Kotov, V. and Nikitina, E. (2002) Reorganisation of Environmental Policy in Russia: The Decade of Success and Failures in Implementation and Perspective Quests. Fondazione Eni Enrico Mattei Working Paper Series. 
http://papers.ssrn.com/sol3/papers.cfm?abstract_id=318685

[19] North, D.C. (1994) Institutional Change: A Framework of Analysis. http://ideas.repec.org/p/wpa/wuwpeh/9412001.html\#provider

[20] Levi, M. (1997) A Model, a Method, and a Map: Rational Choice in Comparative and Historical Analysis. In: Lichbach, M. and Zuckerman, A., Eds., Comparative Politics: Rationality, Culture and Structure, Cambridge University Press, Cambridge, 19-41.

[21] Greener, I. (2005) The Potential of Path Dependence in Political Studies. Politics, 25, 62-72. http://dx.doi.org/10.1111/j.1467-9256.2005.00230.x

[22] Gupta, J., Termeer, C., Klostermann, J., Meijerink, S., van den Brink, M., Jong, P., Nooteboom, S. and Bergsma, E. (2010) The Adaptive Capacity Wheel: A Method to Assess the Inherent Characteristics of Institutions to Enable the Adaptive Capacity of Society. Environmental Science \& Policy, 13, 459-471. http://dx.doi.org/10.1016/j.envsci.2010.05.006

[23] Austin, J. (1832) The Province of Jurisprudence Determined. Richard Taylor, Printer to the University of London, Red Lion Court, Fleet Street, England.

Adachi, Y. (2009) Subsoil Law Reform in Russia under the Putin Administration. Europe-Asia Studies, 61, 1393-1414.

[24] Hart, H.L.A. (1961) The Concept of Law. 2nd Edition, Oxford University Press, London.

[25] Geological Survey of Sweden, SGU (2014) Statistics of the Swedish Mining Industry 2013. Periodiska publikationer 2014. http://resource.sgu.se/produkter/pp/pp2014-2-rapport.pdf

[26] Government Offices of Sweden (2013) Mineral Strategy of Sweden. För ett hållbart nyttjande av Sveriges mineraltillgångar som skapar tillväxt i hela landet. http://www.regeringen.se/content/1/c6/20/96/57/14fbe930.pdf

[27] Government Offices of Sweden: Minerals Act (1991:45).

[28] Government Offices of Sweden: Environmental Code (1998:808).

[29] Mining Expectorateof Sweden (2012) Utdrag ur SGUs verksamhetsberättelse och årsredovisning 2012. http://www.bergsstaten.se/bergsstat/bergsstaten-verksamhetsberattelse-arsredovisning-2012.pdf

[30] Geological Survey of Sweden, SGU (2013) Statistics of the Swedish Mining Industry 2012. Periodiska publikationer 2013: 2.

[31] Geological Survey of Sweden, SGU (2013) Vägledning för prövning av gruvverksamhet. Dnr 04-2288/2012. 2013-05-31.

[32] Government Offices of Sweden: Prop. 1997/98:90 Följdlagstiftning till miljöbalken.

[33] Directive 2011/92/EU of the European Parliament and of the Council of 13 December 2011 on the Assessment of the Effects of Certain Public and Private Projects on the Environment.

[34] Government Offices of Sweden: Förordning (1998:905) om miljökonsekvensbeskrivningar.

[35] Government Offices of Sweden: Prop. 1997/98:45 Miljöbalk, Part I.

[36] Government Offices of Sweden: Prop. 1988/89:92 omnyminerallagstiftningm.m.

[37] Judgement by the Swedish Environmental Court in Case M 1471-08.

[38] Pettersson, M. and Söderholm, P. (2014) Industrial Pollution Control and Efficient Licensing Processes: The Case of Swedish Regulatory Design. Sustainability, 6, 5401-5422. http://dx.doi.org/10.3390/su6085401

[39] Government Offices of Sweden: Planning and Building Act (2010:900).

[40] Geological Survey of Finland. http://en.gtk.fi/

[41] Mineral Strategy of Finland (2010) http://newprojects.gtk.fi/export/sites/projects/mineralstrategi/dokument/FinlandsMineralstrategi_1.pdf

[42] Government Offices of Finland, Mining Act (621/2011).

[43] Government Offices of Finland, Mining Ordinance (391/2012).

[44] Government Offices of Finland, Mining Act (503/1965) (repealed).

[45] Finnish Ministry of Environment. Working Group Report: YM 23/2014.

[46] Government Offices of Finland, Government Bill, 273/2009.

[47] Forss, M. (2011) Kaivoslaki ja ympäristöoikeudellinen päätöksenteko. Ympäristöjuridiikka, 4, 33-74.

[48] Hollo, E.J. (2013) Talvivaara kyllä, Vuotos ei, Vuosaari kyllä, Fennovoima? Ympäristöjuridiikka, 3-4/2013.

[49] Pirinen, T. (2012) Chapter 7. Finland. In: Richer La Flèche, E., Ed., The Mining Law Review, Law Business Research Ltd, London, 63-72.

[50] Kokko, K. (2003) Biodiversiteettiä turvaavat oikeudelliset periaatteet ja mekanismit. Suomalaisen Lakimiesyhdistyk- 
senjulkaisuja, A-sarja No. 243, Helsinki 2003.

[51] Pölönen, I. (2002) Ympäristövaikutusten arviointimenettelyn funktiot ja laadunvarmistus. Oikeus, 31.

[52] Government Offices of Finland, Nuclear Energy Act (990/1987).

[53] Soudunsaari, L. (2009) Maankäytön suunnittelun menettelytapoja kaivospaikkakunnilla. In: Hentilä, H.L. and Ihatsu, E., Eds., KaSuKat-Kasvun ja supistumisen ohjauskeinot ja elinympäristön laatu-tapauksena pohjoisen Suomen kaivospaikkakunnat, Finalreport, Oulun yliopiston arkkitehtuurin osaston julkaisuja, C 124.

[54] Kokko, K. (2013) Weighing Environmental Information and Itssources in Legal Decision-Making. In: Gipperth, L. and Zetterberg, C., Ed., Miljörättsliga perspektiv och tankevändor, Vänbok till Gabriel Michanek och Jan Darpö, Iustus Förlag, Uppsala, 285-317.

[55] Suvantola, L. (2006) Luonnonsuojelutavoitteiden huomioonottaminen malminetsinnässä ja kaivostoiminnassa. Expertstatement for the Ministry of Trade and Industry.

[56] Government Offices of Finland, Environmental Protection Act (527/2014).

[57] Government Offices of Finland, Environmental Impact Assessment Act (468/1994).

[58] Government Offices of Finland, Ordinance on Environmental Impact Assessment (713/2006).

[59] Government Offices of Finland, Land Use and Building Act (132/1999).

[60] The Finnish Safety and Chemicals Agency (Tukes). http://www.tukes.fi/en

[61] The Constitution of the Russian Federation. http://www.wipo.int/edocs/lexdocs/laws/en/ru/ru003en.pdf

[62] Kotov, V. (2002) Russia’s Mineral Resources: Reconfiguration of Institutional Framework. Conference Paper Series, No. 9, International Conference on Natural Assets, Tagaytay City, 8-11 January 2003, Political Economy Research Institute and Center for Science and the Environment, 1-27.

[63] Adachi, Y. (2009) Subsoil Law Reform in Russia under the Putin Administration. Europe-Asia Studies, 61, $1393-1414$. http://dx.doi.org/10.1080/09668130903134814

[64] Locatelli, C. and Rossiaud, S. (2011) A Neoinstitutionalist Interpretation of the Changes in the Russian Oil Model. Energy Policy, 39, 5588-5597. http://dx.doi.org/10.1016/j.enpol.2011.04.053

[65] Government Offices of Russian Federation. Federal Law No. 2395-1 of 21 February 1992, “On Subsoil”.

[66] Global Investment Center (2013) Russia Oil and Gas Exploration Laws, Regulations Handbook, Volume 1, Strategic Information, Regulations, Contacts. International Business Publications, Washington.

[67] Government Offices of Russian Federation. Federal Law No. 7-FZ of January 10, 2002 on Environmental Protection.

[68] Government Offices of Russian Federation. Federal Law No. 174-FZ of 23 November 1995 on Ecological Expertise.

[69] Petrov, V. (2014) Environmental Regulation of Mining Industry in Russian Legislation (Manuscript).

[70] Nysten-Haarala, S., Helenius, H. and Klyuchnikova, E. (2015) Law and Self-Regulation—Substitutes or Complements in Gaining Social Acceptance? Resources Policy, in Press.

[71] Melekhin, Y.S. (2013) Legal Regulation of Geological Studies in the Modern Context. Mineral Resources of Russia. Economics \& Management, 1, 52-54.

[72] Mahony, J. and Thelen, K. (2010) A Theory of Gradual Institutional Change. In Mahony, J. and Thelen, K., Eds., Explaining Institutional Change. Ambiguity, Agency, and Power, Cambridge University Press, Cambridge, 1-37.

[73] Beare, M.J. (2009) Comparison of the Russian and International Approaches to Mining Project Design and Permitting, paper presented at Canadian Institute of Mining, Toronto Canada, 14 May 2009. http://www.srk.com/files/File/SRK\%20UK/Publisher\%20Articles/CIM\%20tech\%20paper\%20008.pdf

[74] OECD (2006) Environmental Policy and Regulation in Russia. The Implementation Challenge. http://www.oecd.org/env/outreach/38118149.pdf

[75] Government Offices of Russian Federation. Federal Law No. 219-FZ “Amendments to the Federal Environmental Law". 